INSIGHTS INTO REGIONAL DEVELOPMENT

ISSN 2669-0195 (online) http://jssidoi.org/ird/

2019 Volume 1 Number 2 (June)

http://doi.org/10.9770/ird.2019.1.2(1)

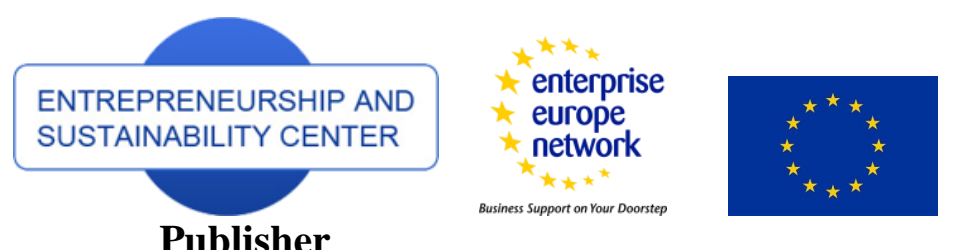

http://jssidoi.org/esc/home

\title{
UNDOING GENDER INEQUALITIES: INSIGHTS FROM THE PORTUGUESE PERSPECTIVE*
}

\author{
Maria Johanna Schouten \\ University of Beira Interior (UBI) and Interdisciplinary Centre of Social Sciences, University of Minho \\ (CICS.NOVA.UMinho), Estrada do Sineiro, 1, 6200254 Covilhã, Portugal \\ E-mail: schouten@ubi.pt
}

Received 15 March 2019; accepted 25 April 2019; published 30 June 2019

\begin{abstract}
In Portugal and elsewhere in the world, the movement promoting gender equality has known advances and setbacks over the past century. While acknowledging and outlining the major favourable developments, this paper discusses mainly some tendencies in the opposite direction, in particular those that highlight and encourage, from an early age, differences between men and women, usually to the detriment of the latter. Examples in Portugal include the growing genderization of children's toys and books (which in one case has triggered a widely-mediatized polemic in September 2017) and the importance of the colours pink and blue. After childhood, differences persist regarding choice of study, professional activities, salary and domestic responsibilities. In this respect, sociological research in Portugal has observed a backlash in the position of women, in particular as an effect of the financial and economic crisis in the period 2010-2014.
\end{abstract}

Keywords: gender inequality; feminism; Portugal; education; domestic context

Reference to this paper should be made as follows: Schouten, M.J. 2019. Undoing gender inequalities: insights from the Portuguese perspective, Insights into Regional Development 1(2): 85-98. https://doi.org/10.9770/ird.2019.1.2(1)

JEL Classifications: J00

Additional disciplines (besides field of economics reflected in JEL classifications): sociology.

${ }^{*}$ Parts of this text are spinoffs from research in the framework of the project Time allocation and Technology - A gender approach for the Portuguese context, funded by the FCT (PIHM/2008/37) and FEDER funds through the European Regional Development Fund COMPETE programme.
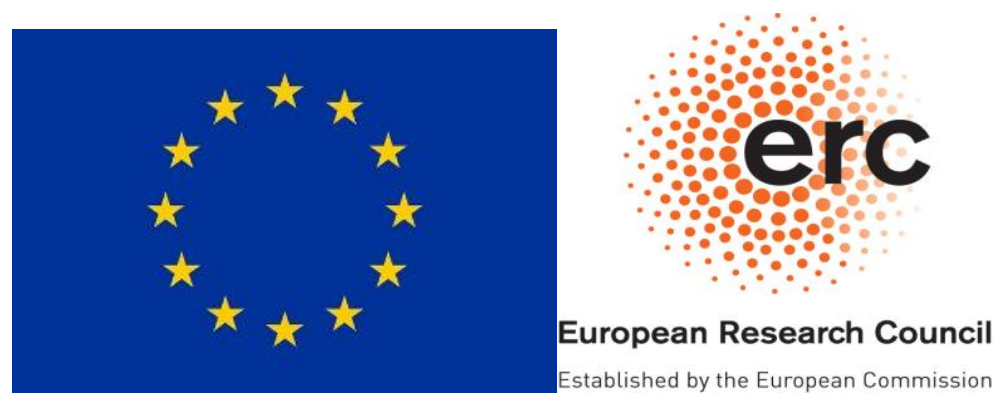
INSIGHTS INTO REGIONAL DEVELOPMENT

ISSN 2669-0195 (online) http://jssidoi.org/ird/

2019 Volume 1 Number 2 (June)

http://doi.org/10.9770/ird.2019.1.2(1)

\section{Introduction}

Since the 18th century, the hope for a time when men and women can live in an equal society has permeated progressive and feminist movements. Virginia Woolf, in her essay "Women and fiction", written in the 1920s, noted that despite recent civil victories, women continued to face many injustices, both structural and in their daily lives, but she also dreamt of the coming of better times. In the last sentence of the essay, alluding to the lack of opportunities for women to develop their talents, she put these hopes into words, "looking ahead to that golden, that perhaps fabulous age when women will have what has so long been denied them - leisure, and money, and a room to themselves" (Woolf 1929: 187). The first victories of feminism in her country gave her cause to imagine a future era in which these resources would be available to women. Should this come to pass, it would be a "golden age", but if not, it would be a "fabulous age", existing only in fables or fairy tales.

Glimmers of hope were also seen in early 20th-century Portugal. These included a nascent feminist movement. Its aims, primarily to achieve greater civil rights and better education for women, were not well received by society as a whole, and the use of the term "feminism" to describe their struggle even less so. Speaking in 1905, Ana de Castro Osório, one of the movement's leading figures, said, "In Portugal [feminism] is a word which still causes laughter or outrage in men, depending on their temperament, and which causes most women to blush, the poor wretches, as if it were a grave error committed by some of their fellow women, for which they are not responsible, praise the Lord!" (Osório 1905:11). The hope in this lament lies in the word "still", which reveals the author's belief in the dawning of a better age, in which the cause of gender equality, and the use of the word "feminism" to describe the movement advocating this fairer situation, would be accepted as normal.

In the century that separates our times from those of Ana de Castro Osório and Virginia Woolf, major steps have been made towards achieving gender equality, but we are far from realising the dreams of these authors. The term feminism continues to incite revulsion or discomfort, feelings evoked by the provocative title of the volume edited by Ann Oakley and Juliet Mitchell (1997), Who is afraid of feminism? In the same decade, Lígia Amâncio (1998: 80) observed a feeling of horror towards "feminists" among university students, stemming from their own ignorance. Today, years later, few of my own students would label themselves feminists if asked during their first lesson. The image of "women who want to dominate men", and of feminism as the female equivalent of "chauvinism" prevails. The existence of male feminists is relatively unknown and even considered ridiculous.

It is not only the term feminism that lacks widespread acceptance today, but also the aim of this movement, namely equality of opportunities irrespective of gender. In part, this hostile or indifferent stance toward feminism is a result of its own success. For many, the fact that women now occupy positions such as minister, judge or director is a sign that equality has already been achieved, rendering its advancement unnecessary. Some people even hold the view that women are privileged beings, illustrated, for example, by constant comments about the high proportion of women among the student population. Another objection to feminism justifies social differentiation on the basis of the natural difference between the sexes which, according to this line of thought, impacts greatly on their respective skills and personalities.

In reality, appearances conceal prevailing injustices (Silva et al. 2016). Women in top positions do not compensate for the overall inequality of the labour market, in which women are overrepresented in lower income categories and less prestigious professions and roles (Acker 2009; Santos and Amâncio 2014; Boulis and Jacobs 2008; WEF 2017; Eurostat 2018). The increasing division between traditionally feminine and traditionally masculine sectors is worthy of careful consideration (Coontz 2012). Moreover, initiatives to improve the balance between extra-domestic work and private life, which would mainly benefit women, have encountered obstacles, resulting in part from the precarious working arrangements that have become prevalent. 
INSIGHTS INTO REGIONAL DEVELOPMENT

ISSN 2669-0195 (online) http://jssidoi.org/ird/

2019 Volume 1 Number 2 (June)

http://doi.org/10.9770/ird.2019.1.2(1)

These negative developments in terms of gender equality replicate a pattern seen throughout history. Frequently, such setbacks have reversed the road towards justice, for example the emancipation of certain sections of the population (Wertheim 1971). Sometimes, it is a case of two steps forward, one step back, but sometimes three backwards steps are taken. Above all, it is a long and winding road.

This paper discusses the winding road towards realising greater equality between the genders, considering two factors; "images of gender" on the one hand and "socioeconomic and political context" on the other. Many authors have argued that the first of these factors (which concerns identity and stereotypes) is decisive. On the basis of many studies, Cecilia Ridgeway (2011) pointed to the persistence of what she calls "common knowledge" about the genders, which is more difficult to transform than "material structures". The author demonstrates that throughout major processes of societal transformation in America, gender inequality has remained a constant, always adapting to the new circumstances (Ridgeway 1997; 2011). This rule also seems to apply in Portugal, the difference being that since the transition to democracy in 1974, governmental authorities and civic associations in our country have done more to explicitly promote gender equality. The fact that legal and social change alone has not succeeded in achieving firmly rooted material equality seems to demonstrate the dominance and tenacity of gendered stereotypes. This is nothing new, and is evidenced by the great focus on representations in studies of gender inequality, an approach seen in Portugal in the pioneering work of Lígia Amâncio (1994).

Thus, this text will explore these trends in Portugal, using examples relating to the two aforementioned areas. The first topic concerns the fundamental role of education and upbringing, including teaching materials, in the development of gender identity. The second topic relates to the domestic setting, in particular the division of housework between men and women, an arrangement that conditions their respective opportunities for public life. These two themes are strongly connected, given the great influence of early childhood experiences on the construction of gender identity and representations of men and women. As such, we consider stereotypes and representations (to which Osório alluded) as well as the availability and use of resources such as free time, financial resources and privacy (the desire expressed by Woolf), seeking the interrelationships between these two dimensions.

The next section offers a brief portrait of feminism in Portugal over the last hundred years, initiatives in the field of gender equality and their results. We then present and interpret the two aforementioned cases of advances and setbacks on the path to gender equality, focusing on childhood and practices in the families.

\section{The traject of feminism in Portugal}

As a movement, feminism, the fight for equality between men and women, has never had a solid footing in Portugal. It made a promising start in the early decades of the 20th century, but involvement in this struggle was limited to a small group of elite men and women. The repressive climate that emerged in 1926, after the First Republic, left no room for increasing public awareness, let alone open opposition to gender-based injustices, of which there were many. Women had a precarious legal status, a high rate of illiteracy and suffered most from the poverty and lack of health services, conditions which led, for example, to Portugal's poor position in the European rankings for maternal and infant death (Barreto 2002). In addition to this, anti-feminist ideology was disseminated by the authoritarian Estado Novo regime and the Catholic Church (Cova and Costa Pinto 1997; Pimentel 2001). The few small groups fighting for progress had to act with extreme caution, or even go underground (Esteves 2006; Gorjão 2002; Tavares 2000). 


\section{INSIGHTS INTO REGIONAL DEVELOPMENT}

ISSN 2669-0195 (online) http://jssidoi.org/ird/

2019 Volume 1 Number 2 (June)

http://doi.org/10.9770/ird.2019.1.2(1)

On a national level, the political transition of 1974 led to the drafting of measures to promote equality between the sexes. In Portugal, unlike other counties with a long-established tradition of equal rights movements, the reform initiative came mainly from the government, although there was dialogue with civic associations. The principal official body was the Comissão da Condição Feminina (the Committee on the Feminine Condition, now the CIG - Comissão para a Cidadania e a Igualdade de Género - Committee for Citizenship and Gender Equality), founded in 1977. Prior to this, working groups had already drafted legislation, including the law establishing 90 days statutory maternity leave, which was implemented in 1976 (Monteiro 2010; Monteiro and Ferreira 2012). Portugal's admission to the European Economic Community (now the European Union) in 1986 was another incentive for equality policies, such as the various National Equality Plans.

Furthermore, under the new democratic regime, legal reform targeted diverse aspects of life, aiming to combat the widespread inequality of Portuguese society. As a result of these policies, positive progress was made in many fields, such as the expansion and democratisation of educational and healthcare structures and social services, which also resulted in the creation of jobs, particularly for women. Various specific laws were passed in order to foster gender equality, governing areas including maternity and paternity leave and benefits; the fight against domestic violence; and, more recently, the decriminalisation of voluntary abortion up to 10 weeks and the recognition of the rights of LGBT people. However, there is, at times, considerable discrepancy between the letter of the law and actual practices.

\section{Differentiation, images and education}

Frequently, opponents of feminism resort to the argument of "difference" between men and women. And they do not always understand that the most significant biological difference is the fact that women are capable of becoming pregnant, giving birth and breastfeeding. Rather, this form of biological determinism presupposes a fundamental difference between the sexes in terms of interests, skills and personality. In many cases, this serves to justify the more powerful position of men, either by undervaluing "feminine qualities", or by exalting abilities, such as supposed communication skills, in a "benevolently sexist" discourse (Amâncio 2004: 338; Lima and Sobral 2016). These binary representations are alive as well, as demonstrated by the continuing position on the bestseller lists of the book Men are from Mars, Women are from Venus, in which John Gray (1992) argues that the difference between men and women is so great that communication between them appears impossible. Hundreds of other mass market titles concerning the opposition between men and women have recorded significant sales, such as Why men don't listen and women can't read maps, by Allan and Barbara Pease (2000).

The significance attributed to difference goes hand in hand with the great interest in the sex of a human being, even before birth. Technological advances, in particular ultrasound scans, enable us to better monitor the health and development of babies during gestation. However, for many future mothers and fathers (and their social circle), the most interesting aspect of the 20-week scan is learning their baby's sex. They often claim that there is a practical reason for this curiosity, as knowing the sex is useful when preparing clothing and decorating the baby's room, which, today, must match the sex of the child. Among the middle classes in the United States, this interest has culminated in people holding parties at which the sex of the baby is revealed, the so-called "gender reveal parties". At these events, attendees are officially informed of the sex (not the gender, as the term misleadingly suggests) of the child. They involve an element of suspense, as well as games, cakes and other snacks. The internet and businesses in general are awash with tips on organising this type of party and the products to buy, which prominently feature the colours pink and blue.

This symbolism is a recent construction. Differentiation of the sexes using colour originated in the United States, where, curiously, 100 years ago pink indicated a boy as it was considered "stronger" and blue was for girls 


\section{INSIGHTS INTO REGIONAL DEVELOPMENT}

ISSN 2669-0195 (online) http://jssidoi.org/ird/

2019 Volume 1 Number 2 (June)

http://doi.org/10.9770/ird.2019.1.2(1)

(Paoletti 2012). My own childhood memories also bear witness to the vast range of meaning that such signs can hold, depending on their context. In 1950s and 1960s Holland, the designated colour for babies, regardless of sex, was white. In my Catholic extended family, the preferred colour for older girls was blue, due to the association with Mary, mother of Jesus (Koslosky 2017). What is more, for centuries the clothing worn by small children was not determined by sex (Schouten 2011: 36, note 22). The pictures in my primary school books and old family photographs featured an abundance of boys in skirts.

In today's toy market, the strong differentiation between boys and girls is manifested in the "blue and pink aisles" of large retailers. Differences in toys and games according to sex appear to be universal and to have existed throughout history. This distinction in toys is a subject frequently alluded to as an example of how upbringing and primary socialisation play an active role in the formation of gender identity (Cardona et al. 2015: 11; Taveira and Silva 2014; Auster and Mansbach 2012); and the topic is often covered in gender equality training initiatives. However, the effects of these awareness initiatives and "gender mainstreaming" are not reflected in the range of toys on offer. On the contrary, according to various studies, binary differentiation of these items is greater today than in the 1960s and 70s. Research by Sweet (2014) reveals that, at one time, labelling "for boys" and "for girls" was practically absent from the Sears catalogue, affecting only 2\% of toys in 1975 (cf. Daly 2017). Another example is Lego. When this toy formula was launched in the 1960s, it was aimed at all children, irrespective of gender. However, it has since diverged into female Lego and male Lego, prominently featuring pink and blue. Differentiation generates or reinforces inequality, because it restricts the access of each of the sexes to certain activities, in this case forms of play. Manufacturers and consumers do not appear to consider this a major problem; manufacturers may take the view that producing toys for girls and toys for boys is an opportunity to increase sales.

An imbalance also exists in terms of the information and education available to girls, as demonstrated by the books on offer. The Dangerous Book for Boys (Iggulden 2006), in its Portuguese version advertised in the 2017 FNAC catalogue with the slogan "The book that teaches boys to be boys [...]", has already reached its fourth edition in Portugal. Following the success of this book, the Daring Book for Girls (Buchanan and Peskowitz 2009) was published, featuring the blurb, "the female version of the spectacular Dangerous Book for Boys". This suggests that it is a second thought, aimed at the Second Sex. These books are localised translations of the English and American originals, which have had great international success, inspiring other publishers to produce similar titles. The content of the respective publications deserves further study but appears to reinforce the stereotype of the adventurous male. While girls are encouraged to follow this example to a certain point, they cannot forget supposedly feminine interests, such as knitting. The "masculine" is the norm. The distinct blue and pink covers contribute to the message transmitted to potential buyers.

In terms of books for girls, we cannot neglect to mention a "case" that caused a considerable stir in Portuguese social media in summer 2017. It concerned two versions of a puzzle and activity book designed for children aged four to six, one "for boys" and the other "for girls". Their content differed in line with traditional gender stereotypes. For example, boys were associated with space and "public" activities, while girls are associated with "private" settings. The games and activities also differed, with boys being assigned tasks that involved more "action". In a "technical statement" (2017), the Committee for Citizenship and Gender Equality (CIG) decried the publications and highlighted the setbacks that these activity books could cause in terms of the fight against gender stereotypes. Following the recommendations of the Committee (or the social media outcry), the publisher suspended sale of the books. However, it returned to the shelves of the bookstores the following month.

This intervention fell within the remit of the CIG, primarily because the book represented a teaching material which, given the age of its target users, was sure to have an impact on the formation of their gender identity. West and Zimmerman (1987) argue that this identity is consolidated by the performance of certain activities considered appropriate to a person's gender. This "doing gender" approach, in the authors' own terminology, highlights the 


\section{INSIGHTS INTO REGIONAL DEVELOPMENT}

ISSN 2669-0195 (online) http://jssidoi.org/ird/

2019 Volume 1 Number 2 (June)

http://doi.org/10.9770/ird.2019.1.2(1)

performative and interactional aspect of the concept of gender (Schouten 2016). From an early age, many children assert themselves as girls or boys through performance of these roles. In the family setting, this gender identity tends to be taught and learnt both through play and later through the types of tasks the child is expected to perform (Vieira 2006). In previous generations, the daughters of a family were generally expected to assist in household chores, while sons were not, thus giving them more time for play and study. This practice persists, as illustrated by a statement by a woman in her thirties, whom we interviewed in 2011, in the project about Time and Technology (Schouten et al. 2012). The interviewee did not involve her son in household chores, unlike her friend who had daughters: "...I had a son, but in the case of my friend, she had daughters. She makes her daughters clean. The weekend comes around and one of them dusts, while the other cleans the kitchen. You hear about parents who make their boys work... but not me".

In the preschool and school setting, this difference is accentuated by the social environment. In a recent study, Sales Oliveira and Mendes (2017) report considerable differences in play habits between four to six-year-old boys and girls at preschool. The teacher responsible of the group under scrutiny had recently attended a training course on Education, Gender and Citizenship, organised by the CIG in partnership with the University of Beira Interior (UBI). However, these courses alone are not enough to bring about substantial change, because in the preschool environment a multitude of factors and actors exert an influence on the formation or consolidation of gender identity in children. At a slightly older age, the influence of relationships within peer groups is a key factor in reinforcing gender identities. At school, for example, these are reaffirmed by conversations and behaviour outside of teaching hours, as observed by Maria do Mar Pereira (2012) in her study on adolescents in Lisbon. Boys and girls are treated differently during the teaching and learning process itself, notably by teachers, who implicitly, and perhaps unconsciously, assume a difference in skills between the sexes. Saavedra et al. (2011: 164) refer to international surveys demonstrating that in the hard sciences and technologies, teachers and school textbooks are orientated more towards boys, which may be one reason for the gender imbalance in various scientific fields in higher education.

\section{The domestic context}

Habits within the domestic sphere often hinder the realisation of greater gender equality in society. Traditionally, the fact that women and not men have been responsible for domestic chores and childcare has had a negative impact on their health and limited their leisure and training opportunities, particularly when combined with work outside the home. Feminist movements and relevant institutions have signalled the importance of equality within the private sphere, while also acknowledging the difficulty of influencing what happens behind closed doors. In Portugal, many of the initiatives resulting from the Equality Plans, general law and European programmes such as EQUAL aimed to create conditions that foster more even distribution of housework. To this end, they supported measures aiming to improve the balance between work, family and private life. Among other measures, this involved the provision of leave, better social services and facilities such as crèches, and incentives for companies to offer alternative ways of working.

Despite these measures and the many awareness campaigns, inequalities within the domestic sphere persist. Studies carried out in Portugal (Aboim 2010; Schouten et al. 2012; Wall, Aboim and Marinho 2010) show some alterations in daily routines, in particular with regards to the role of the man within the family, demonstrating a diversification of approaches to fatherhood. However, these are not fundamental changes: women remain responsible for the wellbeing of the family and the home, and continue to be the partner who have less time for themselves. In the first decade of this millennium, there were positive developments, as evidenced by surveys and studies in which we participated (ConVidas 2002-2004; RoMann 2006). However, the second decade saw the re- 


\section{INSIGHTS INTO REGIONAL DEVELOPMENT}

ISSN 2669-0195 (online) http://jssidoi.org/ird/

2019 Volume 1 Number 2 (June)

http://doi.org/10.9770/ird.2019.1.2(1)

emergence of traditional patterns. This development was not unrelated to the austerity policies of 2010-2015, supposedly justified by the financial crisis that occurred during this period (Ferreira and Monteiro 2015).

Gender differentiation manifested itself in the forms and phases in which the measures accompanying the financial and economic crisis which began in 2008 were implemented. Initially, unemployment mainly affected men, as they represented the majority of the workforce in the construction and industrial sectors, the first to reduce staffing numbers (Moura, Spindler and Taylor, 2015: 90; Jordão 2015: 216). Male unemployment did not automatically lead to a fairer distribution of housework, especially not in couples where both partners lost their jobs, which was not unusual during the latter stages. As observed in a survey carried out by Múrias (2015) in rural parishes in Northern Portugal, women in such situations almost always do the majority of housework, while unemployed males have more spare time. Another study of intra-family relationships during times of crisis, in which 803 couples were surveyed, showed an increase in the time men dedicated to household chores, but only during the working week. At the weekend, their contribution did not increase (Ribeiro, Coelho and FerreiraValente 2015; Coelho 2016). For men, habits and norms from the times when they were working persist: the weekend is mainly for leisure. The findings of these 2014 surveys, that male unemployment does not significantly relieve women from housework and childcare duties, are similar to the results of the studies carried out around the turn of the millennium (Afonso and Poeschl 2006).

In these difficult years, the reorganisation of the state budget led to cuts to social services and facilities for the elderly, the chronically ill and children, and the burden of resolving the resulting problems lay mainly with women (family members or neighbours) (Ferreira and Monteiro 2015; Coelho 2016). This extension of their care duties resulted from expectations inherent to the fact that they were female. These expectations existed within their social environment, but were also rooted in their own female being, their identity. As a result, many women who had recently achieved a level of autonomy, thanks to the political and sociocultural changes and initiatives promoting equality, had to surrender some of these conquests.

During the crisis, we witnessed the persistence of ideas about the difference between men and women in terms of their roles, their supposed rights and the ways in which their gender is asserted. Like Ridgeway (2011), we can conclude that stereotypes are so firmly entrenched that social movements struggle to uproot them. In this case, the slowdown of public equality policy and disruption of the economic structure led to the resurrection of old stereotypes. Ribeiro et al. (2015: 79) highlighted the convergence between data collected in their survey, concerning the time that men and women dedicate to housework, and the results of the nationwide survey on the use of time carried out in the late 1990s (Perista 2002). As if to prove the findings of Ribeiro and her fellow authors, a recent survey on the use of time, carried out in 2015, Perista et al. (2016: 59) once again noted an "accentuated gender imbalance" in terms of time dedicated to the activities in question.

It is possible to place one's hopes in the next generation, but the signs are not very promising. Recent studies of university students in Portugal- a group who could be expected to have an open attitude and a desire for changeillustrate the persistence of traditional ideas about the division of tasks between men and women within the family, although not rigidly. A survey of 206 male and 172 female students at the University of Beira Interior, with an average age of 21, carried out in 2010 (Villas-Boas et al. 2014), included questions about the organisation of their future family lives. Almost $80 \%$ of participants (more women than men) stated that they were in favour of equal sharing of household chores. However, with regards to specific tasks, students expected to continue traditional practices, for example women being responsible for the laundry and men being responsible for financial questions and repairs (Villas-Boas et al. 2014: 121-123).

Another survey of students at the Instituto Superior de Economia e Gestão (ISEG- Higher Institute for Economics and Management) was carried out in 2014 by Coelho and Casaca (2017), using a sample of 53 women and 47 men with an average age of 21 . Once again, the vast majority stated that in their future lives they were in favour 


\section{INSIGHTS INTO REGIONAL DEVELOPMENT}

ISSN 2669-0195 (online) http://jssidoi.org/ird/

2019 Volume 1 Number 2 (June)

http://doi.org/10.9770/ird.2019.1.2(1)

of equality between men and women in terms of household chores (Villas-Boas et al. 2014: 121). It is, however, worth highlighting the differing male and female stances on this subject. Of the latter, $96 \%$ were in favour of equality, while this percentage among men was only $78 \%$. This investigation also revealed that young women were less confident with regards to their future professional career, which may be a consequence of stereotypes instilled since childhood, as well as their intention to become a mother in the future, a desire shared by $87 \%$ of female participants.

These surveys indicate a minor shift in views on gender equality within the domestic sphere among well-educated young people, compared to the previous generation. However, doubt remains as to whether their ideas will be put into practice in the future.

\section{Conclusions}

In order to interpret the alternating emancipatory and counter-emancipatory trends outlined in this paper with regards to the role of women, we must consider the ways in which various developments intersect. The largescale structures such as political regimes, which have undergone great changes in Portugal since the beginning of the 20th century, and the economic conjunctures have both exerted an influence, as have other factors, in particular those inherent to gender regimes: identities, images and the praxis of gender.

Virginia Woolf's wish, evoked at the beginning of this paper, was modest: to have money, free time, and a room of her own, without mentioning numbers or demanding equality with men. This desire has been partially fulfilled in Portugal, where the situation of women today is far better than in the mid-20th century. However, they continue to lag behind men in various areas of economic and social life. Women's free time is limited, in particular due to the persistence of the double shift, one for paid and the other for unpaid work. Space for themselves continues to be a luxury, only accessible to a few. Even when they temporarily leave the domestic setting, women with families find it difficult to fully mentally disconnect from their household responsibilities (Chesley 2005; Guerreiro and Carvalho 2007; Schouten 2012: 98-101). The greater autonomy won by (and for) women clearly has its limits.

Although the environment, particularly in terms of politics, is favourable to the pursuit of equality between men and women, the internalisation of gender roles by individuals, in combination with the expectations of others, has its effects. It is likely that these representations of gender in particular have brought about the aforementioned setbacks on the road towards equality. Images of gender have not been transformed, but rather recycled to adapt to new social conditions. The changes to symbols, toys and teaching materials cited earlier are, in reality, merely changes to the way stereotypes are expressed, not to the stereotypes themselves. Similar superficial change has been noted in the world of work.

Thus, in the present day, despite the organisational and technological restructuring of the workplace, images and self-perception of gender continue to exert considerable influence on the attribution of tasks and on hierarchical progression (Casaca 2012). The iconic "Luisa" depicted by António Gedeão in his poem Calçada de Carriche (1957) with her monotonous factory job now finds her counterpart in the mostly female supermarket checkout workers who use modern digital technology to perform monotonous operations, often under precarious employment conditions (Cruz 2004). The radical transformation of the world of business, brought about by technological change, has not led to the advent of a new world of work, where both genders have equal opportunities. In reality, on a global level, the prestigious technology sector is increasingly male dominated, to the extent that the organisers of the 2018 World Economic Forum in Davos de 2018 explicitly signalled the retreat of progress towards equality (Martinson 2018). Even in the more modest high-tech environment of a call 


\section{INSIGHTS INTO REGIONAL DEVELOPMENT}

ISSN 2669-0195 (online) http://jssidoi.org/ird/

2019 Volume 1 Number 2 (June)

http://doi.org/10.9770/ird.2019.1.2(1)

centre, Matos (2014) noted that men tend to occupy technical support roles, while women are relegated to customer service, playing to gender stereotypes about their superior communication skills.

Government measures can promote equality (as they have in Portugal at various points since the revolution of 25 April 1974) or, on the contrary, they can push women (back) into the domestic sphere and/or subordinate positions, as was the case under the Estado Novo regime. The recent backlash went hand in hand with the economic and financial crisis, which brought about a reduction of social benefits, services and facilities and a major increase in unemployment and economic hardship for families. As a rule, it was women who tried to resolve these problems, extending their duties as a caregiver and giving up leisure activities, education and work. In these years, the fragility of the rights won by women in Portugal became evident.

Ridgeway (2011, 2013) called attention to the slowness of gender stereotypes (in her words, common knowledge) to change, thus favouring a focus on training and shifting perceptions. However, in Portugal, the crucial role of upbringing and education continues to be countered by other trends. As already stated, a great proportion of the (formal and informal) socialisation of children highlights the differences between men/boys and women/girls, thus restricting the range of opportunities for girls, while also mentally setting them up for a future of inequalities. Moreover, in certain areas, the differentiation between masculine and feminine is more marked today than in previous decades. This is one of the setbacks experienced during the period discussed in this paper, which run in parallel, or alternate, with advances towards gender equality.

In order to put the dreams of Virginia Woolf into context, it is important to remember that were expressed shortly after women in the United Kingdom has won universal suffrage, ten years after a specific section of the female population was given the right to vote. In February 2018, to celebrate the centenary of this first step, the Guardian newspaper published testimonies by five female writers on their predictions for the next 100 years (Atwood 2018). None of them were optimistic. In her contribution, journalist Polly Toynbee evoked the optimism of the Western world in the 1970s, when equality seemed to be well within reach, and contrasts this with the disillusioned climate of 2018. In light of the setbacks mentioned, she calculated that equality would take four generations to achieve. Yet more pessimistic is the recent message from Portugal, reflected in an opinion piece by Sara Falcão Casaca (2018). Referring to the Gender Gap Report of 2017 (also cited in this paper) it is calculated that if progress continues at the same pace, the road to (global) financial gender equality will take 217 years. Progress will also be slow in fields such as health, politics and education.

As history teaches us, it is impossible to accurately predict the future. History also teaches us that during phases of progress and euphoria, such as the era of Ana de Castro Osório and her generation, the first wave of feminists, setbacks can occur. Taking into account the fragile nature of social progress, groups and individuals advocating equality and justice must always remain vigilant and active. These emancipatory actions may take place within social sciences and movements which, faced with the issues raised by this article, must not shy away from being labelled feminist.

Note:

A slightly different version of this article in the Portuguese language, entitled "Desfazendo desigualdades de género: um caminho sinuoso", has been published in Gomes, S. et al (Eds.) (2018). Desigualdades sociais e políticas públicas. Homenagem a Manuel Carlos Silva. Famalicão: Húmus, Pp. 467-486. 
INSIGHTS INTO REGIONAL DEVELOPMENT

ISSN 2669-0195 (online) http://jssidoi.org/ird/

2019 Volume 1 Number 2 (June)

http://doi.org/10.9770/ird.2019.1.2(1)

\section{References}

Aboim, S. 2010. Género, família e mudança em Portugal [Gender, family and change in Portugal], in Wall, K., Aboim, S., Cunha, V. (Eds.), A vida familiar no masculino. Negociando velhas e novas masculinidades, Lisboa: CITE, 39- 66. http://hdl.handle.net/10451/11148

Acker, J. 2009. From glass ceiling to inequality regimes, Sociologie du Travail 51(2): 199-217. https://doi.org/10.1016/j.soctra.2009.03.004

Afonso, R. M.; \& Poeschl, G. 2006. Representaciones del impacto de la situación de desempleo en las prácticas familiares [Representations of the impact of unemployment in family practices], Revista de Psicología Social, 21(3): 241-258. https://doi.org/10.1174/021347406778538221

Amâncio, L. 1994. Masculino e feminino. A construção social da diferença [Male and female. The social construction of the difference]. Porto: Afrontamento.

Amâncio, L. 1998. O feminismo português no final do século XX. Um olhar sobre o passado ausente e a promessa de futuro [Portuguese feminism at the end of the 20th century. A glance at the absent past and the promise of the future], UMAR seminar Movimento feminista em Portugal nos finais do século $X X$, Lisbon. www.umarfeminismos.org/feminismos/docs/seminariomovfeminista.pdf

Atwood, M.; Okolosie, L.; Toynbee, P.; Donald, A.; \& Bindel, J. 2018, February 6. Will women be equal to men in 100 years? The panel verdict, The Guardian. Retrieved from: https://www.theguardian.com/commentisfree/2018/feb/06/will-women-be-equal-men-hundredyears-gender-equality-panel

Auster, C.J.; \& Mansbach, C.S. 2012. The gender marketing of toys: an analysis of color and type of toy on the Disney store website, Sex Roles 67: 375-388. https://doi.org/10.1007/s11199-012-0177-8

Barreto, A. 2002. Mudança social em Portugal, 1960-2000 [Social change in Portugal, 1960-2000], Working paper 6-02. Lisbon: Instituto de Ciências Sociais. http://www.fcsh.unl.pt/docentes/luisrodrigues/textos/Mudança\%20Social\%20em\%20Portugal\%20António\%20Barreto.pdf

Boulis, A. K.; \& Jacobs, J. A. 2008. The changing face of medicine: Women doctors and the evolution of health care in America. Ithaca, NY: Cornell University Press.

Buchanan, A. J.; \& Peskowitz, M. 2009. The Daring Bookfor Girls. New York, NY: William Morrow Company.

Cardona, M. J.; Nogueira, C.; Vieira, C.; Uva, M.; \& Tavares, T. C. 2015, Guião de educação - Género e cidadania - Pré-escolar [Teaching guide - Gender and citizneship - preschool]. Lisboa: CIG. $\underline{\text { https://www.cig.gov.pt/wp- }}$ content/uploads/2015/10/398_15_Guiao_Pre_escolar.pdf

Casaca, S. 2012. Mercado de trabalho, flexibilidade e relações de género: tendências recentes [The labour market, flexibility and gender relations: recente tendencies], in Casaca, S. (ed.), Mudanças laborais e relações de género. Coimbra: Almedina, 9-50.

Casaca, S. 2013. As novas dinâmicas laborais e os desafios da articulação com a vida familiar [The new labour Dynamics and the challenges of the articulation with family life], Sociologia - Problemas e Práticas 72: 31-52. https://doi.org/10.7458/SPP2013722617

Casaca, S. 2018, March 8. A metáfora glass ceiling tem 40 anos. Com quantos mais contará a sua relevância científica, social e política? [The glass ceiling metaphor has existed for 40 years. For how many more will its scientific, social and political value be relevant?] Público. https://www.publico.pt/autor/sara-falcao-casaca

Chesley, N. 2005. Blurring boundaries? Linking technology use, spillover, individual distress, and family satisfaction, Journal of Marriage and Family, 67(5): 1237-1248. https://onlinelibrary.wiley.com/doi/abs/10.1111/j.1741-3737.2005.00213.x

CIG - Comissão para a Cidadania e a Igualdade de Género 2017. Parecer Técnico da CIG relativo aos conteúdos dos Blocos de Atividades da Porto Editora [Technical evaluation of the CIG regarding the contentes of the Activity Books of Porto Editing House]. Retrieved from https://www.cig.gov.pt/2017/08/parecer-tecnico-da-cig-relativo-aos-conteudos-dos-blocos-de-atividades-da-porto-editora/

Coelho, L. 2016. Finanças conjugais, desigualdades de género e bem-estar. Facetas de um Portugal em crise [Conjugal finance, gender inequalitues and well-being. Aspects of a Portugal in crisis], Revista Crítica de Ciências Sociais 111: 59-80. https://journals.openedition.org/rccs/6461 
INSIGHTS INTO REGIONAL DEVELOPMENT

ISSN 2669-0195 (online) http://jssidoi.org/ird/

2019 Volume 1 Number 2 (June)

http://doi.org/10.9770/ird.2019.1.2(1)

Coelho, S.; \& Casaca, S. 2017. Jovens estudantes universitários/as perante a futura vida profissional e familiar: a marca do género [Young university students about their future professional and family life: the influence of gender], Ex aequo 36: 59-75. https://doi.org/10.22355/exaequo.2017.36.04

ConVidas. 2002-2004. Promoção da Conciliação entre a Vida Familiar e Profissional [Promotion of the Conciliation between Family Life and Professional Life]. Project in the framework of the EU Programme EQUAL (nº 2001/EQUAL/A2/IO/164). Covilhã: Beira Serra and University of Beira Interior.

Coontz, S. 2012, September 29. The myth of male decline, The New York Times, retrieved from http://www.nytimes.com/2012/09/30/opinion/sunday/the-myth-of-male-decline.html

Cova, A.; \& Costa Pinto, A. 1997. O salazarismo e as mulheres: uma abordagem comparativa [The Salazarist regime and women: a comparative approach], Penelope 17: 71-94. https://dialnet.unirioja.es/servlet/articulo?codigo=2656445

Cruz, S. A. 2004. Retrato de trabalhadoras da linha de caixa de uma grande superfície [Portrait of female cashiers at a large supermarket], Análise Social 172: 571-594. http://analisesocial.ics.ul.pt/documentos/1332346862C8jTK5ov6Br08RR4.pdf

Daly, N. 2017, January. How today's toys may be harming your daughter, National Geographic magazine. https://www.nationalgeographic.com/magazine/2017/01/gender-toys-departments-piece/

Esteves, J. 2006. Conselho Nacional das Mulheres Portuguesas (1914-1947) [The National Council of the Portuguese Women (19141947)], Faces de Eva. Estudos sobre a Mulher 15: 113-135.

EUROSTAT. 2018, March 7. Women in the EU earned on average 16\% less than men in 2016, Eurostat Newsrelease 38/2018. http://ec.europa.eu/eurostat/en/web/products-press-releases/-/3-07032018-BP

Ferreira, V.; \& Monteiro, R. 2015. Austeridade, emprego e regime de bem-estar social em Portugal: em processo de refamilização? [Austerity, employment and welfare regime in Portugal: in the process of re-familization?], Ex aequo 32: 49-67. https://doi.org/10.22355/exaequo.2015.32.01

Gorjão, V. 2002. Mulheres em tempos sombrios. Oposição feminina ao Estado Novo [Women in dark days. Female opposition to the Estado Novo], Lisboa: Imprensa de Ciências Sociais.

Gray, J. 1992. Men are from Mars, women are from Venus. New York, NY: HarperCollins.

Guerreiro, M.; \& Carvalho, H. 2007. O stress na relação trabalho-família: uma análise comparativa [Stress in the relation between work and family: a comparative analysis], in Wall, K. \& Amâncio, L. (Eds.), Família e género em Portugal e na Europa, Lisboa: Imprensa de Ciências Sociais, 129-179. https://ciencia.iscte-iul.pt/publications/28372/export

Gutek, B.A.; Searle, S.; \& Klepa, L. 1991. Rational versus gender role explanations for work-family conflict, Journal of Applied Psychology 76: 560-568. http://dx.doi.ord/10.1037/0021-901076.4.560

Iggulden, C. 2006. The dangerous book for boys, New York, NY: HarperCollins.

Jordão, C. 2015. Review of Maria Karamessini and Jill Rubery (Eds.) (2014), Women and Austerity: The Economic Crisis and the Future for Gender Equality, New York, Routledge, Ex cequo 32:201-218. https://exaequo.apem-estudos.org/artigo/32-karamessini-maria-ruberyjill-org-2014-women-and-austerity-th

Koslosky, Ph. 2017. Why is the Blessed Virgin Mary always wearing blue? Retrieved from https://aleteia.org/2017/06/24/why-is-theblessed-virgin-mary-always-wearing-blue/

Lima, M. L.; \& Sobral, J. M. 2016. Desigualdades de género e novas formas de sexismo [Gender inequalities and new forms of sexismo], in Silva, M.C. et al. (Eds.), Desigualdades e políticas de género. Vila Nova de Famalicão: Húmus, 161-190.

Matos, P. de. 2014. Gender commodification and precarity in Portuguese call centres: the (re)production of inequality, Etnográfica 18, 1: 5-32. https://journals.openedition.org/etnografica/3319 
INSIGHTS INTO REGIONAL DEVELOPMENT

ISSN 2669-0195 (online) http://jssidoi.org/ird/

2019 Volume 1 Number 2 (June)

http://doi.org/10.9770/ird.2019.1.2(1)

Monteiro, R. 2010. A emergência do feminismo de Estado em Portugal: uma história da criação da Comissão da Condição Feminina [The emergence of state feminism in Portugal: a history of the creation of the Comission of the Female Condition]. Lisbon: CIG.

Monteiro, R.; \& Ferreira, V. 2012. Metamorfoses das relações entre o Estado e os movimentos de mulheres em Portugal: entre a institucionalização e a autonomia [Metamorphoses in the relations between the state and the women's movements in Portugal: between institutionalization and autonomy], Ex cequo 25: 13-27. http://www.scielo.mec.pt/pdf/aeq/n25/n25a03.pdf

Moura, T.; Spindler, E.; \& Taylor, A. 2015. Portugal's Masculinities Crisis: Gender equality in the era of flagging economies, Ex aequo 32: 87-100. https://doi.org/10.22355/exaequo.2015.32.06

Múrias, C. 2015. Experiências de conciliação: analisando as relações de género durante a atual crise económica [Experiences of conciliation: an analysis of gender relations during the current economic crisis], Ex aequo 32: 101-115. https://doi.org/10.22355/exaequo.2015.32.07

Osório, A. de Castro 2015 [1905], Às mulheres portuguesas [To the Portuguese women], edited by A. Neves and F. Catarino, coord. by Â. Correia, Lisbon: Bibliotrónica portuguesa.

Paoletti, J. 2012. Pink and blue: telling the boys from the girls in America. Bloomington: Indiana University Press.

Pease, A.; \& Pease, B. 2001. Why men don't listen and women can't read maps. New York NY: Harper Collins.

Pereira, M. 2012. Fazendo género no recreio. A negociação do género em espaço escola. [Doing gender at break time. Negotiating gender at school]. Lisbon: Imprensa de Ciências Sociais.

Perista, H. 2002. Género e trabalho não pago: os tempos das mulheres e os tempos dos homens, Análise Social 163: 447-474. http://analisesocial.ics.ul.pt/documentos/1218732780P9jPM6nt5Ik17YP4.pdf

Perista, H.; Cardoso, A.; Brázia, A. Abrantes, M.; \& Perista, P. 2016. Os usos do tempo de homens e de mulheres em Portugal [The uses of time by men and women in Portugal.]. Lisbon: CESIS and CITE.

Pimentel, I. 2001. História das organizações femininas do Estado Novo [History of the women's organizations during the Estado Novo]. Lisboa: Temas e Debates.

Ribeiro, R.; Coelho, L.; \& Ferreira-Valente, A. 2015. Unemployment and Gender Equality within the Family in Portugal, Ex aequo 32: 69-85. https://doi.org/10.22355/exaequo.2015.32.05

Ridgeway, C. L. 1997. Interaction and the conservation of gender inequality: Considering Employment, American Sociological Review 62(2): 218-235. http://dx.doi.org/10.2307/2657301

Ridgeway, C. L. 2011. Framed by gender: how gender inequality persists in the modern world. Oxford: Oxford University Press.

RoMann. 2006. Rolle der Männer - Vereinbarkeit von Beruf und Privatleben in kleinen und mittelständischen Unternehmen. Mit Beispielen aus Deutschland, Frankreich, Portugal und Ungarn. Covilhã, Berlin, Budapest, Paris. http://hdl.handle.net/10400.6/6255.

Sales Oliveira, C.; \& Mendes, A. 2017. Brincar ao género: socialização e igualdade na educação pré-escolar [Playing gender: socialization and equality at pre-school, Ex cequo 36: 167-186. https://doi.org/10.22355/exaequo.2017.36.10

Santos, M. H.; \& Amâncio, L. 2014. Sobreminorias em profissões marcadas pelo género: consequências e reações ["Superminorities" in gendered professions: consequences and reactions], Análise Social 212: 700-726. http://analisesocial.ics.ul.pt/documentos/AS_212_d04.pdf

Schouten, M. J. 2011. Uma sociologia do género [A sociology of gender]. Vila Nova de Famalicão: Húmus.

Schouten, M. J. 2012. Stress e uso do tempo no espaço doméstico [Stress and time use in the domestic context], in Matos, A.D. and Schouten, M. J. (Eds.), Saúde: sistemas, mediações e comportamentos. Vila Nova de Famalicão: Húmus, 91-108.

Schouten, M. J. 2016. Identidades de género: tempo e tecnologia no espaço doméstico [Gender identities: time and technology in the domestic contexto], in Silva, M.C. et al. (Eds.), Desigualdades e políticas de género. Vila Nova de Famalicão: Húmus, 61-76.

Schouten, M. J.; Araújo, E.; Augusto, A.; Simões, M. J.; Sousa, H.; \& Las Heras, S. 2012. Tempo e tecnologia: Uma abordagem de género para o contexto português. Relatório do projeto de investigação [Time and technology. A gender approach for the Portuguese context. 
INSIGHTS INTO REGIONAL DEVELOPMENT

ISSN 2669-0195 (online) http://jssidoi.org/ird/

2019 Volume 1 Number 2 (June)

http://doi.org/10.9770/ird.2019.1.2(1)

Report of the research project]. Covilhã: Universidade da Beira Interior/ Braga, Universidade do Minho. http://hdl.handle.net/1822/24105. http://hdl.handle.net/10400.6/3296

Silva, M. C.; Lima, M. L.; Sobral, J. M.; Araújo, H.; \& Ribeiro, F. (Eds.) 2016. Desigualdades e políticas de género [Inequalities and policies of gender]. Vila Nova de Famalicão: Húmus.

Sweet, E. 2014, December 9. Toys are more divided by gender now than they were 50 years ago, The Atlantic, https://www.theatlantic.com/business/archive/2014/12/toys-are-more-divided-by-gender-now-than-they-were-50-years-ago/383556/

Tavares, M. 2000. Movimentos de mulheres em Portugal - Décadas de 70 e 80 [Women movements in Portugal-The 1970s and 1980s]. Lisbon: Livros Horizonte.

Vieira, C. 2006. É menino ou menina? Género e Educação em Contexto Familiar [Is it a boy or a girl? Gender and education in the family contexto]. Coimbra: Almedina.

Villas-Boas, S.; Sales Oliveira, C.; \& Las Heras, S. 2014. Tarefas domésticas e género: representações de estudantes do ensino superior [Household chores and gender: representations of university students], Ex aequo 130: 113-129. https://doi.org/10.22355/exaequo.2014.30.08

Wall, K.; Aboim, S.; \& Marinho, S. 2010. Perfis de paternidade no Portugal contemporâneo [Profiles of paternity in present-day Portugal], in Wall, K. Aboim, S. and Cunha, V. (Eds.), A vida familiar no Masculino. Negociando velhas e novas masculinidades. Lisbon: CITE, pp. 313-332.

WEF - World Economic Forum. 2017. The Global Gender Gap Report, Cologny/Geneva, World Economic Forum.

Wertheim, W.F. 1971. Evolutie en revolutie. De golfslag der emancipatie [Evolution and revolution. The waves of emancipation]. Amsterdam: Van Gennep.

West, C.; \& Zimmerman, D. H. 1987. Doing gender, Gender \& Society 1(2): 125-151.

Woolf, V. 1929, March- Women and fiction, The Forum: 179-187. http://www.unz.org/Pub/Forum-1929mar-00179?View=PDF

\section{Aknowledgements}

Parts of this text are spinoffs from research in the framework of the project Time allocation and Technology - A gender approach for the Portuguese context, funded by the FCT (PIHM/2008/37) and FEDER funds through the European Regional Development Fund COMPETE programme.
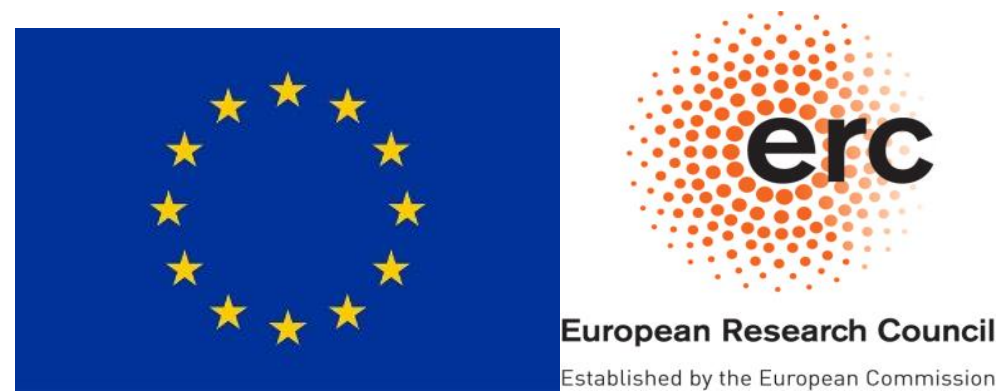
INSIGHTS INTO REGIONAL DEVELOPMENT

ISSN 2669-0195 (online) http://jssidoi.org/ird/

2019 Volume 1 Number 2 (June)

http://doi.org/10.9770/ird.2019.1.2(1)

Maria Johanna Christina SCHOUTEN is Associate Professor of Sociology at the University of Beira Interior, Portugal. She has obtained a PhD in social and cultural sciences at VU University Amsterdam, and «agregação» in Sociology at the University of Beira Interior. Research and teaching activities mainly in Portugal and Indonesia. Main areas of interest: Gender Studies; Sociology and Anthropology of Health; Sociology of Ageing; History of Anthropology; Anthropology and History of Southeast Asia.

ORCID ID: http://orcid.org/0000-0001-5191-3916

Register for an ORCID ID:

https://orcid.org/register

Copyright (C) 2019 by author(s) and VsI Entrepreneurship and Sustainability Center

This work is licensed under the Creative Commons Attribution International License (CC BY).

http://creativecommons.org/licenses/by/4.0/

(c) (1) Open Access 